望引に関する研究（その3） 一中国近世の東洋的体操法一

東京教育大学 弆 原瑛

中国近世の道書，医書，養生書には，「千金方」「諸 病源候論」等にみる古典導引法が収録され，或はそれら から拨萃して構成された新らしい体系を見出すのであ ろ.ここでは思想的, 社会的なものを背景にして新らし く構成された各種酎引法の休系を類型的に分類し，内容 分析を試みる。

この期の養生法及び導引法にみられる著しい特色の一 つは，方法の合理化，簡略化をめさんている点であろ 5。次に一例として，策代の蒲処貫が天子に献納した 「保生要録」の序文を少しく紹介する。人開の生命はも とより自然の事物に至るまで，その本質に逆った手段を 仕向故ると, 当然保てる寿命が短かくなり, 本質に 「合理的」な手段を代向けると，元来短命なるべきもの までが，引替えて長寿を保てるよらになるといら事を，

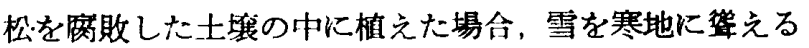
陰山の幽谷に蔵った場合に例をとって説明している。

次に先人が書き残していった保少に関する著書小節日
が煩わしく，徒らに神秘的な手段に捉われて，普通の修 善では近付くことのできぬよらなるのになってしまって いる事を云い，神仙の道は決して神秘的なものでなく， もともと「平易简単」なものだったのだといら事を力説 している，その順序として，先ず第一に，神気を体内上 り取逃したり，活したりしないよらに注意する。この次 には，運動（導引）により肢体を調節する。それから衣 服の調節・居処の撰択・蒋飼方・领食の衛生等に及ぶの である．ᄂかし本書を読んで，具体的であっても，まだ とこやらに徹底しないよらな怎が残るのだが，だんだん と新らしい方法も考えられてきて，遂には遺憾なきまで に具体的にその手段が講じられるようになる。「三才図 会」kは導引坐功中, 最も理論的に完成したものと云わ れている陳希夷 24 気坐功法が収録されている。これは 天地自然の法則は，そのまま人問にあてはまるものであ るとなし，陰陽の原理の応用によって導引の方術を理論 づけ体系化しようと企てている．明代には八段錦法と命 名された立派な導引法が螎みだされ，行なら者に極めて わかり易く説明されている，また十八段錦において有機 的組織観は大成されている。

\section{仏教経典における身体䤄 一起信論について一}

淑徳大学 策 田 基 行

序身体的なるのの理念を捉える試みとして，仏教 経典にみられる身・体などを取りあげる，文献に大乗起 信論と T. Richard の The Awakening of Faith を 使用する，成立 5〜6世紀で馬鳴といわれているが，成 立事情に関する思想史的背景や作者については不明な点 が多い：しかし大乗仏教の哲学的思想をのべた基本的原 典として高く評価されている，本論汢以下の体系により 構成せられる。帰敬弁意分，因緑分（Ｉ），立義分（】），

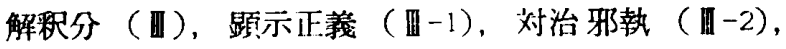
分別発趣道相（圈-3)，修行信心分（IV)，勤街利益分 ( V).

身出所回数 46, 用法, 回数, 出所の順に示せば, 身 (3)（目-1，3）彼身 (1)（序)，其身 (1)（田-3），法身 (26) $\{\mathbb{\|}-1(16), \mathbb{I}-2(2), \mathbb{I}-3(8)\}$ ，応身 (4) $(\mathbb{I}-1)$, 己身 (3) (II-1)，衆牛身 (1) (N)，有身 (1) (N)，智身 (1) (11-1) で，特に身心(5)出，一切の身心の苦を受け… （II-1），法性には身心の相なく（II-3），虚しく一切の 身心の大沾を受けて（IV），身心適悦して不彾不曷なら しめ (N)，己に一切の身心の大苫を受け（N）がある.

体出所回数 38 で体 (19) 伃 (1)，【(1), 四-1 (10),

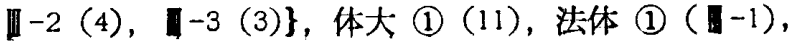

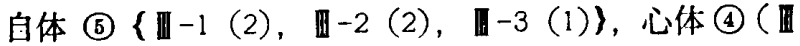
-1), 智体 (1) (1-1)，其体 (1) (1-1)，同体 (1)（四1)，体性 (2) (目-3)，体相 (2) (I-1)，仏体 (1) (I-3) などがある。

考 身には body の概䧔がつきやすい，法身 (the Eternal the Divime Body)，彼身 (embody), 其身 (manifested bodies), 有身 (the bodies of all living beings), 身心 (mine and boyd) がそれであ る。体は全部 nature である。体 (nature), 自体 (nature of its own), 体性. (man's nature), 心体 (the mind's being), 智体 (True Real Nature of the mind) で，体からは body の概念㥂られない. body は色で晛らわされる場合がある．能説の人は色心（His body and mind) の業淃れたれば（1）である。しかし 色の英訳表現は複䧴で all phenomena などさまさまで ある。

結 語 身心の場合の身が body に接近している。 身心を Richard は mind and body, 色心を body and mind としており，心身の成立過程を明らかにする上で 與味ある問題である。四書と共に body を適切に表現 する概念はみられない点で雨者は一致するが，四書で身 は行為的主体の意味で，体にいくらかの body の概念 をみるといらことから，四書と仏教経典とでは身及び体 の意味が全く対立的に異なった概念の上に用いられてい るといえよう。 